A notícia da consumação, trouxe-a, há trinta dias, um recorte de jornal de Montevidéu (22):

"Desta maneira foi sepultado êste homem, de tão relevante prestígio dentro e fora de nosso país, o qual, em seu último mo mento, deu-nos também a outra lição, a da religiosidade, pois que, na lucidez de seus sentidos, recebeu os últimos Sacramentos e os auxílios espirituais de nossa religião".

\title{
O CENTENÁRIO DE UMA GRANDE VIDA
}

\section{JOSE' SALGADO MARTINS}

Catedrático de Direito Penal

O Rio Grande do Sul comemorou, a 29 de julho de 1957, o centenário do nascimento de Joaquim Francisco de Assis Brasil.

Síntese, no mais alto grau, das melhores virtudes da gente riograndense, Assis Brasil foi o exemplar perfeito do homem de pensamento e do homem de ação.

Escritor, orador, parlamentar, diplomata, político na acepção mais alta e nobre da palavra, o preclaro cidadão riograndense imprimia a tôdas as manifestações do pensamento e a todos os atos em que se concretizava a sua conduta pública e privada, o signo, a altitude e o fulgor de uma personalidade de exceção.

Desde muito jovem, ainda nos bancos acadêmicos, na tradicional Faculdade de Direito de São Paulo, revela os grandes predicados com que a Providência o dotou para desempenhar 0 eminente papel a que estava destinado.

Na predicação da República, forjou e aprimorou o seu talento de escritor, orador e pensador político, um dos mais insignes, de sóbria elegância, preciso, brilhante e vigoroso na exposição, na crítica e no debate. Historiador, escreveu lúcido ensaio sôbre as causas da República riograndense de 1835 , que é, ao mesmo tempo, um ensaio sociológico e político sôbre uma das fases mais expressivas da sociogênese do Rio Grande do Sul. Pensador, dentre vários e brilhantes trabalhos de conteúdo jurídico e político, escreveu "Do Governo Presidencial na República Brasileira" e "Democracia Representativa". Orador soberbo, ao modêlo ciceroneano e demostênico casava harmoniosamente o sentido moderno da oratória política, de feição mais britânica que gauleza, sem perder os primores da elegância e do brilho no conceber e no dizer, ao lado do timbre de graça, bom gôsto e imaginacão. O discurso que proferiu em 1908, na fundacão do Partido Republicano Democrático, representa um dos mais notáveis diplomas da eloquência política em língua portuguêsa, ao qual não falta, sequer, a fidelidade ao modêlo clássico: o exórdio ou preâmbulo 
em que o orador estabelece o primeiro elo de comunicação com o seu auditório, preparando-o para a exposição ulterior, a parte central em que expõe a tese e os argumentos que a confortam, e a peroração em que condensa, na nota emotiva e arrebatadora, as grandes linhas do discurso, que decidem, em última análise, do êxito ou do fracasso do orador.

Do mesmo brilho e da mesma elevação, revestiu-se a sua ação de diplomata. Ministro Plenipotenciário nos Estados Unidos da América do Norte, continuou a tradição fulgurante de Nabuco. Embaixador do Brasil junto ao Governo de Portugal, foi extraordinàriamente fecunda a sua atuação. Como Enviado Especial e Ministro Plenipotenciário junto à República Argentina, após a Revolução de 30 , foi o último serviço que prestou ao país, na sua representação exterior.

Ao lado de Rio Branco, o deus Terminus da nacionalidade, na expressão feliz de Euclides da Cunha, firmou o Tratado de Petrópolis que dirimiu definitivamente a questão do Acre e incorporou ao patrimônio territorial do Brasil uma área de 200.000 $\mathrm{km} 2$. que se encontrava em poder da Bolívia.

Homem do grande mundo, pela sensibilidade e pela cultura, era, no entanto, Assis Brasil comovedoramente fiel às suas origen de campesino, orgulhoso filho da campanha e da estância rio grandense. Êsse sentido de profunda comunhão com a terra era o traco marcante de sua notável personalidade.

Espírito singular que tanto sabia projetar e executar um instrumento de trabalho rural e resolver um problema de zootecnia ou de cultura agrícola, quanto discorrer sôbre um tema de história, de direito ou de política, ou sôbre os assuntos mais sedutores do pensamento artístico, literário ou filosófico de autores modernos ou antigos.

Assis Brasil, no patrimônio cultural do Rio Grande e do Brasil, é uma eminência solar, cuja fulguração mais se intensificará à medida em que, sob novos ângulos, for estudada a sua pujante e extraordinária figura.

\section{A CRISE DO NORMATIVISMO JURÍDICO E A EXIGÊNCIA DE UMA NORMATIVIDADE CONCRETA}

MIGUEL REALE

Presidente do Instituto Brasileiro de Filosofia. Diretor da Sociedade Interamericana de Filosofia. Catedrático de Filosofia do Direito na Faculdade de Direito da Universidade de São Paulo.

1 - O problema da normatividade como elemento essencial da experiência jurídica é dos que mais têm suscitado distincõos radicais na Filosofia do Direito contemporânea e, isto não obstante, talvez assista razão a KARL OLIVECRONA quando assevera que, inexplicàvelmente, se tem atribuido pouca importância a uma precisa determinação do conceito de norma ( $L$ 'im perativo della legge, "separata" da Rev. JUS, Dezembro, 1954, fasc. IV, pág. 452).

Se, de um lado, a Escola do Direito Puro de HANS KELSEN reduz o Direito a um sistema escalonado de normas, segundo uma estrita exigência formal, de outro lado, há jurisfilósofos que o concebem precipuamente em têrmos de experiência ou de conduta, quer sejam estas expressões empregadas empiricamente, à maneira dos "juristas sociólogos", quer segundo um enfoque transcendental ou axiológico, como nos estudos de GIUSEPPE CAPO. GRASSI ou de CARLOS COSSIO. Entre êsses dois extremos do Direito-norma e do Direito conduta, entre a racionalidade abstrata correspondente à primeira concepção e a exigência de concreção revelada na segunda, desenvolve-se uma série variegada de posições doutrinárias, as quais correspondem às duas tendências que atuam poderosamente na evolução do Direito: uma tendência no sentido do primado da ordem, e da certeza, muito embora com sacrifício de certas qualidades ou características peculiares a cada uma das ocorrências da vida social; uma outra que, recorrendo até mesmo a fôrças intuitivas ou a-racionais, corre o risco de 